TRAN THI HONG PHUONG*

ANNA WRÓBLEWSKA-KURDYK*

KATARZYNA DANCEWICZ*

BEATA GABRYŚ*

\title{
SELECTIVE ACCEPTANCE OF BRASSICACEOUS PLANTS \\ BY THE PEACH POTATO APHID MYZUS PERSICAE: \\ A CASE STUDY OF AURINIA SAXATILIS
}

\begin{abstract}
The probing behavior of Myzus persicae (Sulz.) was examined on the ornamental plant Aurinia saxatilis (L.) Desv. that has not been known as a host of M. persicae in nature, and compared to the behavior on cultivated plants of the genus Brassica, B. rapa L. ssp. pekinensis L. and B. oleracea var. gongyloides, that are known hosts to this aphid. The purpose was to determine whether $A$. saxatilis can be exploited by $M$. persicae thus providing a potential refuge for the aphid population. The EPG (Elelctrical Penetration Graph) study demonstrated that on A. saxatilis, M. persicae showed mainly non-probing activities that occupied $70 \%$ of experimental time. The remaining time, which was probing, consisted mainly of pathway activities divided into numerous short probes not reaching beyond 1-2 cell layers and very few aphids reached phloem vessels. None aphid was able to ingest sap in a sustained way. In contrast, on Brassica plants, the probing of $M$. persicae was rarely interrupted, all aphids reached sieve elements
\end{abstract}

\footnotetext{
* Department of Botany and Ecology, University of Zielona Góra, Szafrana 1, 65-516 Zielona Góra, Poland, e-mails: tt.hongphuong@gmail.com; A.Wroblewska@wnb.uz.zgora.pl; k.dancewicz@wnb.uz.zgora.pl; b.gabrys@wnb.uz.zgora.pl
} 
elements and ingested sap for long and uninterrupted periods. It is postulated that high content of glucosinolates in the outer tissues of A. saxatilis leaves may be responsible for the termination of $M$. persicae probing at the very early stage, thus preventing the contact with vascular elements and the ingestion of phloem sap. In consequence, A. saxatilis is rejected as a host plant by M. persicae.

Keywords: glucosinolates, probing behavior, EPG, Chinese cabbage, kohlrabi, basket of gold

\section{Introduction}

The peach potato aphid Myzus persicae (Sulz.) (Hemiptera: Aphididae) is highly polyphagous and according to Blackman and Eastop (1985) it can infest plants of over 40 different families, including many economically important ones worldwide. Among others, it is a common pest of cultivated plants of the family Brassicaceae (= Cruciferae). Brassicaceae comprise 350 genera and more than 3000 species that occur mainly in the Northern Hemisphere (Hegi 1986). Being notable components of all kinds of natural plant associations, agricultural landscapes, and ornamental arrangements, the brassicaceous plants play an important role as hosts and reservoirs for many phytophagous insects, including $M$. persicae (Nault and Styer 1972). However, several widespread plants of Brassicaceae family, such as the ornamental basket of gold Aurinia saxatilis (L.) Desv., have never been listed as hosts for the peach potato aphid. This may suggest the existence of variation in susceptibility of brassicaceous plants to M. persicae despite its broad polyphagy. Considering the commonness of A. saxatilis in home gardens and communal green areas, it is important to determine whether this plant species can function as a host plant for the peach potato aphid population. M. persicae is a vector of more than 100 plant virus diseases, therefore it is crucial to define the possible reservoirs of this aphid population.

The acceptability of a host plant for an aphid is often measured by its quality as a food source, especially in studies on plant resistance mechanisms (Montllor, Tjallingii 1989). An aphid can evaluate the chemical properties of the plant only while its stylets are penetrating plant tissues from epidermis to vascular elements (Harrewijn 1990). Therefore, valuable information on resistance factors and their location in plant tissues, which may affect feeding, is provided by monitoring of 
aphid probing behavior using the electrical penetration graph (EPG) technique (Tjallingii, Mayoral 1992). The analysis of parameters derived from EPG (frequency, duration and sequence of different waveforms) may reflect behavioral responses of aphids to differences in plant suitability (Mayoral et al. 1996).

The aim of the present study was to determine whether $A$. saxatilis can be utilized as a host by $M$. persicae. For this purpose, the probing behavior of M. persicae on A. saxatilis was examined and compared to the behavior on cultivated plants of the genus Brassica, B. rapa L. ssp. pekinensis L. and B. oleracea var. gongyloides, that are well known host plants of this aphid.

\section{Material and Methods}

The laboratory culture of M. persicae was maintained on Chinese cabbage Brassica rapa L. ssp. pekinensis L. M. persicae probing behavior was monitored on $B$. rapa ssp. pekinensis (the plant it was reared on), which was considered as a control plant, kohlrabi B. oleracea var. gongyloides, and basket of gold Aurinia saxatilis. Aphids and plants were kept in the laboratory at $20^{\circ} \mathrm{C}, 65 \%$ r.h., and L16:8D photoperiod. The stock colonies were kept as follows: an adult aphid was placed on a plant and allowed to reproduce for 24 hours. Then the female was removed and the remaining larvae were allowed to develop. Young, 2-3 days old (i.e., 2-3 days after the final moult) viviparous apterous females were selected for experiments. The plants used in the bioassays were 5-6 weeks old.

Aphid probing was monitored using the technique of electronic registration of aphid probing in plant tissues, known as EPG (Tjallingii 1995). In this experimental set-up, aphid and plant are made parts of an electric circuit, which is completed when the aphid inserts its stylets into the plant. Weak voltage is supplied in the circuit, and all changing electric properties are recorded as EPG waveforms that can be correlated with aphid activities and stylet position in plant tissues (Tjallingii 2001). Aphids were attached to a golden wire electrode with conductive silver paint and starved for $1 \mathrm{~h}$ prior to the experiment. Probing behavior of 20 apterous females per studied plant/aphid combination was monitored for 8 $\mathrm{h}$ continuously with a four-channel DC EPG recording equipment. Each aphid was given access to a fresh plant. The plant electrode was placed in the soil. Signals were saved and analyzed using the PROBE 3.1 software provided by W. F. Tjallingii (EPG-Systems, Dillenburg 126703 CJ Wageningen, The Netherlands). The following aphid activities were distinguished: $\mathrm{np}$ - non probing, $\mathrm{C}$ - pathway 
(probing in non-vascular tissues), $\mathrm{G}$ - xylem phase, $\mathrm{E}$ - phloem phase (divided into E1 and E2 that represent watery salivation and sap ingestion, respectively) (Gabryś 2000). The parameters derived from EPGs were analyzed according to their frequency and duration in configuration related to activities in peripheral and vascular tissues. The incomplete (i.e., shorter than 8 hours) recordings were excluded from analysis. The values of EPG parameters were analyzed using Mann-Whitney U-test.

\section{Results}

The EPG recording revealed all kinds of aphid activities related to plant penetration: non-probing, pathway phase ' $\mathrm{C}$ ' that included the unidentified ('derailed') stylet movements ' $F$ ', phloem watery salivation and sap ingestion 'E1' and 'E2', respectively, and xylem sap uptake 'G'. 'F' and 'G' activities occurred sporadically and irrespective of a treatment.

The typical behavior of M. persicae on control Chinese cabbage B. rapa subsp. pekinensis consisted mainly of probing activities ( $93 \%$ of experimental time), which were associated with pathway and phloem phases: 38 and 55\% of the probing time, respectively (Tab. 1). Aphids typically had 16 probes of approximately 28 minutes duration. Non-probing intervals between probes were relatively short, generally less than 2.5 minutes. In the period that preceded the first phloem phase, the probes were usually longer than 2 minutes and $50 \%$ of these probes were longer than 10 minutes (Fig. 1). All aphids reached sieve elements during the 8-hour experiment (50\% of them during the initial 2 hours after having access to the plant) and more than $90 \%$ of these aphids ingested sap in a sustained way (Tab. 1, Fig. 2). There were usually two phloem phases per aphid, which included watery salivation E1 as well as sap ingestion E2. Generally, the proportion of salivation was very low (<7\%) (Tab. 1). On kohlrabi B. oleracea var. gongylodes, probing activities consisted mainly of the phloem phase (61\%) while non-probing occupied approximately $6 \%$ of experimental time (Tab. 1). The mean number of probes was 13.5 per aphid of 33 minute average duration. $75 \%$ of probes before the first phloem phase were longer than 2 minutes and 30\% of them were probes longer than 10 minutes (Fig. 1). All aphids reached sieve elements during the 8-hour experiment ( $50 \%$ of them during the initial 1 hour after having access to the plant) and more than $94 \%$ of these aphids ingested sap in a sustained way (Tab. 1, Fig. 2). There were usually six phloem phases per aphid, which included 
watery salivation E1 as well as sap ingestion E2. Generally, the proportion of salivation was very low $(<6.5 \%)$ (Tab. 1$)$.

On basket of gold $A$. saxatilis, $M$. persicae showed mainly non-probing activities that occupied $70 \%$ of experimental time. The remaining time, which was probing, consisted mainly of pathway activities divided into 43 probes of average 3.3 minute duration (Tab. 1). The probes that preceded the first phloem phase were usually short, i.e., less than 2 minutes long (Fig. 1). 21\% of aphids reached phloem vessels during the 8-hour experiment and none of them ingested sap in a sustained way. The proportion of salivation during phloem phase reached $21 \%$ (Tab. 1, Fig. 2).

Table 1. Summary of Myzus persicae activities during probing on Brassica rapa ssp. pekinensis, B. oleracea var. gongyloides, and Aurinia saxatilis

\begin{tabular}{|l|l|l|l|l|}
\hline Plant & & $\begin{array}{l}\text { Brassica rapa } \\
\text { ssp. pekinensis } \\
\mathrm{n}=11\end{array}$ & $\begin{array}{l}\text { Brassica oleracea } \\
\text { var. gongylodes } \\
\mathrm{n}=17\end{array}$ & Aurinia saxatilis \\
\hline $\begin{array}{l}\text { Total duration of } \\
\text { non-probing }\end{array}$ & $\min$ & $35.4 \pm 8.3$ & $31.3 \pm 8.0$ & $\mathrm{n}=14$ \\
\hline Number of probes & $\#$ & $16.0 \pm 2.2$ & $13.5 \pm 2.5$ & $43.5 \pm 26.4$ \\
\hline $\begin{array}{l}\text { Proportion of probes } \\
\text { with phloem phase }\end{array}$ & $\%$ & $11.8 \pm 2.5$ & $30.1 \pm 8.3$ & $2.3 \pm 2.0^{*}$ \\
\hline $\begin{array}{l}\text { Number of phloem } \\
\text { phases }\end{array}$ & $\#$ & $2.5 \pm 0.5$ & $6.6 \pm 1.6$ & $0.4 \pm 0.3^{*}$ \\
\hline $\begin{array}{l}\text { Proportion of phloem } \\
\text { phase in probing } \\
\text { activities }\end{array}$ & $\%$ & $54.9 \pm 7.9$ & $61.2 \pm 6.8$ & $1.4 \pm 1.2^{*}$ \\
\hline $\begin{array}{l}\text { Proportion of saliva- } \\
\text { tion in phloem phase }\end{array}$ & $\%$ & $6.7 \pm 5.9$ & $6.4 \pm 2.8$ & $21.4 \pm 11.4^{*}$ \\
\hline $\begin{array}{l}\text { Proportion of aphids } \\
\text { with phloem phase }\end{array}$ & $\%$ & $100.0 \pm 0.0$ & $100.0 \pm 0.0$ & $21.4 \pm 1.1^{*}$ \\
\hline $\begin{array}{l}\text { Proportion of aphids } \\
\text { with sustained sap } \\
\text { ingestion }\end{array}$ & $\%$ & $91.1 \pm 9.1$ & $94.1 \pm 5.9$ & $\pm 0.0^{*}$ \\
\hline
\end{tabular}

Values represent means $( \pm \mathrm{SE})$. Asterisks indicate statistically significant differences in relation to control (B. rapa ssp. pekinensis) (Mann-Whitney U-test; $\mathrm{p}<0.05), \mathrm{n}=$ number of aphids analysed, ${ }^{\mathrm{a}}-$ only aphids with phloem phase were counted. 


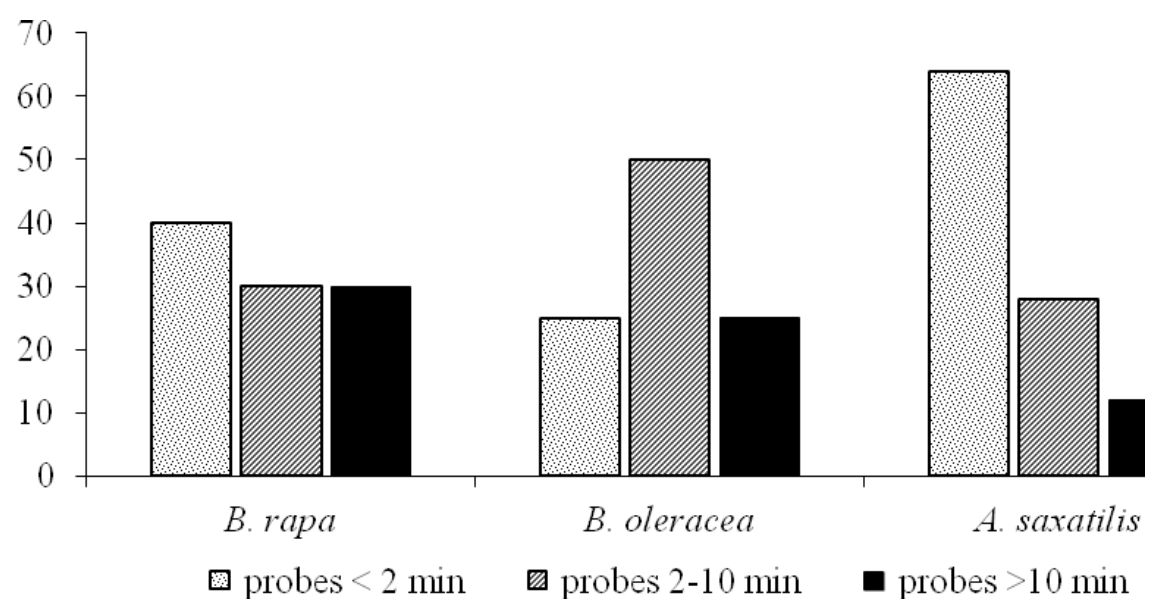

Figure 1. Proportion of brief ( $<10 \mathrm{~min})$ and long (2-10 $\mathrm{min}$ and $>10 \mathrm{~min}$ ) probes before the first phloem phase in Myzus persicae during probing on Brassica rapa ssp. pekinensis, B. oleracea var. gongyloides, and Aurinia saxatilis

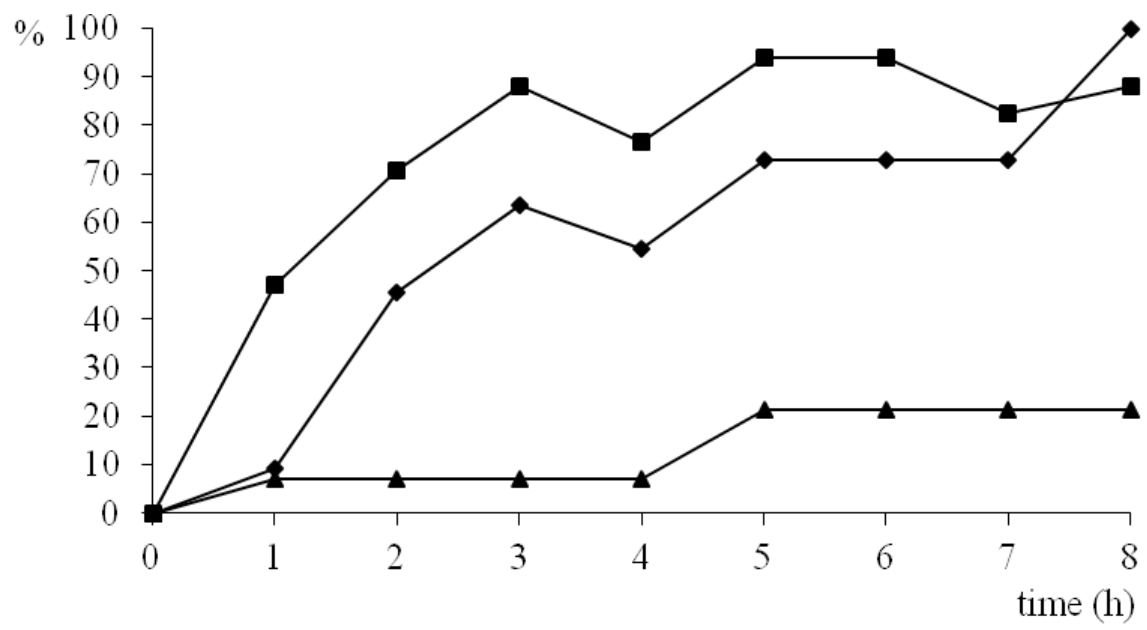

$\multimap$ B. rapa $\rightarrow-$ B. oleracea $\longrightarrow$ A. saxatilis

Figure 2. Cumulative proportion of Myzus persicae individuals with phloem phase on Brassica rapa ssp. pekinensis, B. oleracea var. gongyloides and Aurinia saxatilis during the 8-hour EPG experiment 


\section{Discussion}

The present study confirmed the high suitability of cultivated plants of the genus Brassica for the peach potato aphid: on B. rapa L. ssp. pekinensis L. as well as on $B$. oleracea var. gongyloides, phloem sap ingestion was the main activity during probing. At the same time, the probing towards sieve elements was rarely interrupted and, in consequence, phloem phase was reached within 1-2 hours after aphids had been given access to the plants. Moreover, the proportion of salivation into sieve elements during phloem phase was very low (6-7\%), which is typical for the behavior of aphids on host plants that lack feeding deterrents (van Helden and Tjallingii 1993; Gabryś et al. 2015). In contrast, M. persicae avoided probing and never accepted phloem sap on $A$. saxatilis. The proportion of salivation during phloem phase was 3.5 times higher than on control plants, which indicates the presence ongestion-impeding factors in the sap (Halarewicz, Gabryś 2012).

Plants of the family Brassicaceae contain specific secondary compounds called glucosinolates. Toxic to unspecialized insects (Feeny 1977) the glucosinolates stimulate feeding of the cabbage aphid Brevicoryne brassicae L. which depends exclusively on brassicas (Matile 1984). In low concentrations, glucosinolates can be tolerated by some polyphagous insects, such as the peach potato aphid, and under certain conditions even act as weak phagostimulants (Kunkel 1977). When infesting brassicaceous plants, $M$. persicae selects for old and senescing parts, especially the leaves (Van Emden 1972, 1978; Gabryś, Tjallingii 1999). This behavior have been explained as a preference for highly nutritious and amino acid-rich phloem sap in senescing leaves due to protein decomposition (Van Emden, Bashford 1969). At the same time, old and senescing leaves contain relatively small amounts of glucosinolates in contrast to the young leaves (Gabryś et al. 1997). However, M. persicae ingests sap from as many sieve elements in young as in the old leaves and there is no difference in time spent on phloem sap ingestion (Gabryś, Tjallingii 1999). M. persicae contacts and ingests glucosinolates during penetration through plant tissues and during sap ingestion from sieve elements: glucosinolates were traced in $M$. persicae honeydew (Gabryś, Tjallingii 1999; Bohinc et al. 2012). The excretion of intact glucosinolates in honeydew by the peach potato aphid is considered a strategy of the avoidance of glucosinolate insecticidal properties (Bohinc et al. 2012). A. saxatilis contains aliphatic (gluconapin, glucobrassicanapin, glucoberteroin, glucoraphanin, glucoalyssin) and indolyl (4-hydroxyglucobrassicin, 4-methoxyglucobrassicin) 
glucosinolates, which also occur in plant tissues of various species of Brassica (Fahey et al. 2001; Griffiths et al. 2001; Iranshahi 2012). There are reports that many of the wild plants belonging to the same family as plants of agronomic importance often contain larger quantities of glucosinolates than their cultivated relatives (Bohinc et al. 2012). Indeed, the concentration of glucosinolates in A. saxatilis is two-threefold greater than in Brassica napus (Griffiths et al. 2001). The toxic and deterrent properties of glucosinolates occurring in high concentrations have been considered responsible for M. persicae reduced performance and its avoidance of the glucosinolate-rich plant parts under natural conditions (Nault, Styer 1972; Van Emden 1972; Dixon 1985). In the present study, we found that M. persicae is not deterred from puncturing leaf surface of $A$. saxatilis. However, it is very likely that the high concentration of glucosinolates in A. saxatilis tissues hinders the probing of $M$. persicae as early as during penetration of subepidermal tissues thus preventing the contact with sieve elements and the ingestion of these metabolites with the phloem sap.

\section{Conclusions}

The basket of gold Alyssum saxatilis can not be exploited as a host plant by the peach potato aphid Myzus persicae. A strong deterrent effect of glucosinolates in subepidermal tissues is probably responsible for the low probing success on A. saxatilis: few aphids reach sieve elements and none is able to ingest phloem sap in a sustained way.

\section{References}

Blackman R.L., Eastop V.F. 1985. Aphids on the World's Crops: An Identification Guide. John Wiley and Sons, Chichester-New York-Brisbane-Toronto-Singapore.

Bohinc T., Ban S.G, Ban D., Trdan S. 2012. Glucosinolates in plant protection strategies: a review. Arch. Biol. Sci., 64: 821-828.

Dixon A.F.G. 1985. Aphid Ecology. Blackie, Glasgow, pp. 13-14.

Fahey J.W., Zalcmann A.T., Talalay P. 2001. The chemical diversity and distribution of glucosinolates and isothiocyanates among plants. Phytochemistry, 56: 5-51.

Feeny P. 1977. Defensive ecology of the Cruciferae. Annals of Missouri Botanical Garden, 64: 221-234. 
Gabryś B. 2000. Powiązania między owadami i roślinami - badania nad mechanizmami odporności roślin na żerowanie mszyc. Biotechnologia, 3: 69-80.

Gabryś B., Tjallingii W.F. 1999. Behavioural responses of the cabbage aphid and the peach-potato aphid to glucosinolates in their host plants. Aphids and Other Homopterous Insects, 7: 203-208.

Gabryś B., Dancewicz K., Gliszczyńska A., Kordan B., Wawrzeńczyk C. 2015. Systemic deterrence of aphid probing and feeding by $\beta$-damascone analogues. Journal of Pest Science, 88: 507-516.

Gabryś B., Tjallingii W.F., van Beek T.A. 1997. Analysis of EPG recorded probing by the cabbage aphid on host plant parts with different glucosinolate contents. Journal of Chemical Ecology, 23 (7): 1661-1673.

Griffiths D.W., Deighton N., Nicholas A., Birch E., Patrian B., Baur R., Stadler E. 2001. Identification of glucosinolates on the leaf surface of plants from the Cruciferae and other closely related species. Phytochemistry, 57: 693-700.

Halarewicz A., Gabryś B. 2012. Probing behavior of bird cherry-oat aphid Rhopalosiphum padi (L.) on native bird cherry Prunus padus L. and alien invasive black cherry Prunus serotina Erhr. in Europe and the role of cyanogenic glycosides. ArthropodPlant Interactions, 6 (4): 497-505.

Harrewijn P. 1990. Resistance mechanisms of plant genotypes to various aphid species. In: Aphid-Plant Genotype Interactions. R.K. Campbell, R.D. Eikenbary (eds.). Elsevier Science Publishers, Amsterdam, pp. 117-130.

Hegi G., 1986. Illustrierte Flora von Mitteleuropa. Verlag Paul Parey, Berlin-Hamburg.

Iranshahi M. 2012. A review of volatile sulfur-containing compounds from terrestrial plants: biosynthesis, distribution and analytical methods. Journal of Essential Oil Research, 4: 393-434.

Kunkel H. 1977. Membrane feeding systems in aphid research. In: Aphids as virus vectors. K.F. Harris, K. Maramorosch (eds.). Academic Press, New York-San Francisco-London, pp. 311-338.

Leszczyński, B. 1996. Kurs praktyczny w zakresie chemicznych interakcji owady-rośliny na przykładzie mszyc Aphidodea. Wyższa Szkoła Rolno-Pedagogiczna, Siedlce.

Matile P. 1984. Das toxische Kompartiment der Pflanzenzelle. Naturwissenschaften, 71: $18-24$.

Mayoral A.M., Tjallingii W.F., Castanera P. 1996. Probing behaviour of Diuraphis noxia on five cereal species with different hydroxyamic acid levels. Entomologia Experimentalis et Applicata, 78: 341-348.

Montllor C.B., Tjallingii W.F. 1989. Stylet penetration by two aphid species on susceptible and resistant lettuce. Entomologia Experimentalis et Applicata, 52: 103-111. 
Nault L.R., Styer W.E. 1972. Effects of sinigrin on host selection by aphids. Entomologia Experimentalis et Applicata, 15: 423-437.

Tjallingii W.F., Mayoral A.M. 1992. Criteria for host plant acceptance by aphids. In: Proceedings $8^{\text {th }}$ Int. Symposium on Insect-Plant Relationships. S.B.J Menken, J.H. Visser, P. Harrewijn (eds.). Kluwer Academic Publishers, Dordrecht, pp. 280-282.

Tjallingii W.F. 1995. Aphid-plant interactions: What goes in the depth of the tissues? Proceedings Experimental \& Applied Entomology, 6: 163-169.

Tjallingii W. 2001. Plant penetration by aphids as revealed by electrical penetration graphs. Aphids and Other Homopterous Insects, 8:105-120.

Van Emden H.F. 1972. Aphids as Phytochemists. In: Phytochemical Ecology. J.B. Harborne (ed.). New York, Academic Press, pp. 25-43.

Van Emden H.F. 1978. Insects and secondary plant substances - an alternative viewpoint with special reference to aphids. In: Biochemical aspects of plant and animal coevolution. J.B. Harborne (ed.). London, Academic Press, pp. 309-323.

Van Emden H.F., Bashford M.A. 1969. A comparison of the reproduction of Brevicoryne brassicae and Myzus persicae in relation to soluble nitrogen concentration and leaf age (leaf position) in the brussels sprout plant. Entomologia Experimentalis et Applicata, 12: 351-364.

Van Helden M., Tjallingii W.F. 1993. Tissue localisation of lettuce resistance to the aphid Nasonovia ribisnigri using electrical penetration graphs. Entomologia Experimentalis et Applicata, 68: 269-278.

\section{ZRÓŻNICOWANIE PODATNOŚCI ROŚLIN KRZYŻOWYCH BRASSICACEAE NA ŻEROWANIE MSZYCY BRZOSKWINIOWEJ MYZUS PERSICAE: STUDIUM PRZYPADKU AURINIA SAXATILIS}

\section{Streszczenie}

Porównano zachowanie mszycy brzoskwiniowej Myzus persicae (Sulz.) podczas penetracji tkanek roślinnych smagliczki skalnej Aurinia saxatilis (L.) Desv., niewykazywanej jako roślina żywicielska $M$. persicae w naturze oraz kapusty pekińskiej $B$. rapa L. ssp. pekinensis L. i kalarepy B. oleracea var. gongyloides, które są znanymi roślinami żywicielskimi tego gatunku mszycy. Celem badań było stwierdzenie, czy A. saxatilis jako powszechnie uprawiana roślina ozdobna może stanowić potencjalne refugium dla M. persicae. Elektroniczna rejestracja żerowania mszyc (EPG) wykazała, że aktywności niezwiązane z penetracją tkanek roślinnych przez $M$. persicae na $A$. saxatilis stanowiły ponad 70\% czasu eksperymentu. Pozostałe aktywności obejmowały głównie krótkie na- 
kłucia tkanek, które nie sięgały głębiej niż 1-2 warstwy komórek. Większość mszyc nie wykazała fazy floemowej, a pozostałe nie wykazały żerowania ciągłego. Na roślinach z rodzaju Brassica, penetracja tkanek roślinnych nie była z reguły przerywana, wszystkie mszyce wykazały fazę floemową i okresy żerowania trwały stosunkowo długo i nieprzerwanie. Wydaje się, że wysoka zawartość glukozynolanów w powierzchniowych tkankach liści $A$. saxatilis powoduje zaprzestanie penetracji tkanek przez $M$. persicae na wczesnym stadium, zapobiega dotarciu do tkanki przewodzącej i pobieranie soku floemowego przez mszyce i w konsekwencji powoduje brak akceptacji A. saxatilis jako rośliny żywicielskiej.

Słowa kluczowe: glukozynolany, żerowanie mszyc, EPG, kapusta pekińska, kalarepa, smagliczka

Cite this article as: Phuong T.T.H., Wróblewska-Kurdyk A., Dancewicz K., Gabryś B. 2015. Selective acceptance of brassicaceous plants by the peach potato aphid $M y$ zus persicae: a case study of Aurinia saxatilis. Acta Biologica, 22: 39-49. 
